\title{
Psychosocial Correlates of Depression in Children and Adolescents with Epilepsy in a Nigeria Neuro-Psychiatric Hospital Ogun OC ${ }^{1}$, Gbiri $\mathrm{CA}^{2 *}$, Akinola $\mathrm{OA}^{1}$, Akinola $\mathrm{OE}^{1}$, Ajirotutu OF${ }^{1}$, Fasesan $\mathrm{OA}^{1}$ and Oye $\mathrm{AO}^{1}$
}

${ }^{1}$ Federal Neuro-Psychiatric Hospital, Yaba, Lagos, Nigeria

${ }^{2}$ College of Medicine, University of Lagos, Idi-Araba, Lagos, Nigeria

\begin{abstract}
Background: Depression is mostly reported psychiatric disorders in children with epilepsy.

Aim: To investigate prevalence of depression among Nigeria children and adolescents with epilepsy and explore associated variables.

Methods: Study involved 57 participants between 7-18years, diagnosed of epilepsy in a Nigeria mental-healthinstitution. Depression and illnesses-perception were assessed using Child-Attitude-towards-IIIness-Scale and Centerfor-Epidemiology-Study-Depression-Scale respectively. Data was analysed using Spearman's Correlation Coefficients and multiple regression $(p<0.05)$.

Results: Participants were aged $13.8 \pm 3.3$ years with onset of seizure between $1-17$ years (mode $=9 y e a r s)$ and presentation in the clinic between 2-17 years (mode $=11$ years). About $40 \%$ were diagnosed of depression. About $44 \%$ had varied educational problems. There was significant correlation between depression and each of educationallevel and seizure frequency at presentation. Seizure frequency predicted depression and felt-stigma. Parent's socioeconomic status predicted seizure frequency.
\end{abstract}

Conclusion: There is high prevalence of depression in Nigeria children and adolescents with epilepsy. Epilepsy has negative impact on the psycho-social status of its sufferers.

Keywords: Depression; Children and adolescents; Epilepsy; Nigeria; Neuro-psychiatric hospital

\section{Introduction}

Psychiatric disorders in children with epilepsy are relatively gaining researcher's attention in Nigeria. Depression in children and adolescents with epilepsy is a common but often unrecognized disorder [1-4]. Most frequent psychiatric disorders in epileptics are depression, anxeity and attention deficit hyperactivity disorder [4-7]. Both epilepsy and depression are characterized by a chronic course and poor long-term psychosocial outcome [2]. Authors have identified psychiatric syndromes such as anxiety, depression, and behavioural affective and conversion disorders in people with epilepsy [8-18]. The risk for psychiatric disorders in people with epilepsy have been reported to be three to six times higher than observed in age matched apparently healthy population $[1,15,18]$. It has also been documented that children and adolescents with epilepsy experience more emotional and behavioural problems than healthy controls and others with chronic conditions [9-26].

There are reported higher incidences of psychiatric disorders in children and adolescents with epilepsy in Nigeria than the western world. In Nigeria, the prevalence of psychiatry disorders in children and adolescents with epilepsy ranged between 30\% and 90\% [27-29]. While studies from the western world reported prevalence ranging between $23 \%$ - 70.5\% [4,30-33]. Several studies have reported the negative impact of epilepsy in a child's education, perceived stigma and quality of life [4,21-28]. The secondary impacts of caring for an epileptic child have also been reported with much social and financial burden on both the parent and the immediate society [4,20-22]. Some factors such as uncontrolled seizures, polytherapy and stigma have been indicted as major predictors of psychiatric disorders in epileptics [27].

In past decades, physicians caring for children and adolescents with epilepsy are getting aware of high prevalence of psychiatric disorders in them. However, controversy still exists over factors having important role in the type of psychiatric disorders associated with epilepsy [4] There is also dearth of literature on psycho-social factors associated with depression in children and adolescents with epilepsy. It is still unclear weather certain patient characteristics or epilepsy features are associated with specific psychiatric disorders. Recognition of these factors could lead to earlier diagnosis and intervention. Therefore, this study investigated the prevalence of depression among Nigeria children and adolescents with epilepsy and explored the variables that are associated with depression in patient with epilepsy in children and adolescents with epilepsy at the child and adolescent unit of Federal Neuro-Psychiatry Hospital, Yaba, Lagos, Nigeria.

\section{Materials and Methods}

The participants were 57 (30 males and 27 females) children and adolescents between 7 and 18 years, diagnosed of epilepsy by consultant Psychiatrist and depression using the fourth edition of the Diagnosis and Statistical Manual (DSM-IV) and tenth edition of the International Classification of Diseases (ICD-10) criteria at the Children and Adolescents Centre of a tertiary mental health institution in Nigeria. They were recruited consecutively for a period of 1 year excluding the severe mental retarded and psychotic ones. Their assent and the consent of their parents were obtained before participating in this

*Corresponding author: Caleb Ademola Gbiri, College of Medicine University of Lagos, Idi-Araba, Lagos, Nigeria, Tel: +23-48033598072; E-mail: calebgbiri@yahoo.com

Received January 20, 2012; Accepted May 23, 2012; Published June 04, 2012

Citation: Ogun OC, Gbiri CA, Akinola OA, Akinola OE, Ajirotutu OF, et al. (2012) Psychosocial Correlates of Depression in Children and Adolescents with Epilepsy in a Nigeria Neuro-Psychiatric Hospital. J Clin Case Rep 2:152. doi:10.4172/21657920.1000152

Copyright: (C) 2012 Ogun OC, et al. This is an open-access article distributed under the terms of the Creative Commons Attribution License, which permits unrestricted use, distribution, and reproduction in any medium, provided the original author and source are credited. 
study. The study was approved by the Research and Ethical Committee of the Federal Neuro-Psychiatric Hospital, Yaba, Lagos, Nigeria.

The participants or their primary caregiver gave information on socio-demographic and clinical variables and quality of life through a validated questionnaire. The Child Attitude towards Illness Scale which was completed by the patients through the guidance of their parents

\begin{tabular}{|c|c|c|}
\hline Variables & Frequency & Percentages \\
\hline \multicolumn{3}{|l|}{ Mother's Educational Level } \\
\hline No-formal & 2 & 3.5 \\
\hline Primary & 8 & 14.0 \\
\hline Secondary & 14 & 24.6 \\
\hline Post-secondary & 25 & 43.9 \\
\hline Missing & 8 & 14.0 \\
\hline \multicolumn{3}{|l|}{ Father's Educational Level } \\
\hline No-formal & 1 & 1.8 \\
\hline Primary & 2 & 3.5 \\
\hline Secondary & 15 & 26.3 \\
\hline Post-secondary & 30 & 52.6 \\
\hline Missing & 9 & 15.8 \\
\hline \multicolumn{3}{|l|}{ Personal Possessions } \\
\hline most people & 4 & 7.0 \\
\hline About average & 34 & 59.6 \\
\hline$<$ every other person & 9 & 15.8 \\
\hline Missing values & 10 & 17.5 \\
\hline \multicolumn{3}{|l|}{ House Hold Annual Income } \\
\hline$<\mathrm{N} 131,988$ & 20 & 35.1 \\
\hline N132, 000-N99, 988 & 11 & 19.3 \\
\hline N600, 000-N, 199,988 & 7 & 12.3 \\
\hline $\mathrm{N} 1,900,000$ & 5 & 8.8 \\
\hline Missing & 11 & 19.3 \\
\hline \multicolumn{3}{|c|}{ Seizure Frequency at Presentation } \\
\hline Several times a day & 11 & 19.3 \\
\hline Once/few times daily & 4 & 7.0 \\
\hline Once/few times per week & 5 & 8.8 \\
\hline Once/few times per month & 16 & 28.1 \\
\hline Missing values & 21 & 36.8 \\
\hline \multicolumn{3}{|c|}{ Seizure Frequency at Present } \\
\hline None & 13 & 22.8 \\
\hline Once/few times per week & 3 & 5.3 \\
\hline Few Times per Month & 11 & 19.3 \\
\hline Occasionally & 16 & 28.1 \\
\hline Missing values & 14 & 24.6 \\
\hline \multicolumn{3}{|l|}{ Residence } \\
\hline A whole house & 11 & 19.3 \\
\hline A flat/apartment & 20 & 35.1 \\
\hline A room and a parlour & 12 & 21.1 \\
\hline A room & 5 & 8.8 \\
\hline Missing & 9 & 15.8 \\
\hline
\end{tabular}

Table 1: Socio-Demographic Variables and Clinical History of the Participants.

\begin{tabular}{|c|c|c|}
\hline Variables & Frequency & Percentages \\
\hline \multicolumn{3}{|c|}{ Bad Feeling about the IIIness } \\
\hline Very good & 1 & 1.8 \\
\hline A little good & 4 & 7.0 \\
\hline Not sure & 2 & 3.5 \\
\hline A little bad & 4 & 7.0 \\
\hline Very bad & 46 & 80.7 \\
\hline \multicolumn{3}{|c|}{ Fairness of having the illness } \\
\hline Very good & 4 & 7.0 \\
\hline A little good & 7 & 12.3 \\
\hline Not sure & 2 & 3.5 \\
\hline A little bad & 6 & 10.5 \\
\hline Very bad & 38 & 66.7 \\
\hline \multicolumn{3}{|c|}{ Illness Interfering with ADL } \\
\hline Very often & 12 & 21.1 \\
\hline Often & 4 & 7.0 \\
\hline Sometimes & 15 & 26.3 \\
\hline Not often & 5 & 8.8 \\
\hline Never & 21 & 36.8 \\
\hline \multicolumn{3}{|c|}{ Illness Interfering with Adventure } \\
\hline Very often & 9 & 15.8 \\
\hline Often & 3 & 5.3 \\
\hline Sometimes & 10 & 17.5 \\
\hline Not often & 12 & 21.1 \\
\hline Very often & 23 & 40.4 \\
\hline \multicolumn{3}{|c|}{ IIIness Interfering with Comparative Feelings } \\
\hline Never & 21 & 36.8 \\
\hline Often & 9 & 15.8 \\
\hline Sometimes & 16 & 28.1 \\
\hline Often & 1 & 1.8 \\
\hline Very often & 10 & 17.5 \\
\hline \multicolumn{3}{|c|}{ Good about the illness } \\
\hline Very often & 24 & 42.1 \\
\hline Often & 2 & 3.5 \\
\hline Sometimes & 15 & 26.3 \\
\hline Not often & 7 & 12.3 \\
\hline Never & 9 & 15.8 \\
\hline \multicolumn{3}{|c|}{ Sad about being Sick } \\
\hline Never & 10 & 17.5 \\
\hline Not often & 7 & 12.3 \\
\hline Sometimes & 12 & 21.1 \\
\hline Often & 4 & 7.0 \\
\hline Very often & 24 & 42.1 \\
\hline \multicolumn{3}{|c|}{ Feel Happy Despite Being III } \\
\hline Never & 12 & 21.1 \\
\hline Not often & 13 & 22.8 \\
\hline Sometimes & 12 & 21.1 \\
\hline Often & 5 & 8.8 \\
\hline Very often & 15 & 26.3 \\
\hline \multicolumn{3}{|c|}{ Feel Good As Other Kids } \\
\hline Very often & 19 & 33.3 \\
\hline Often & 4 & 7.0 \\
\hline Sometimes & 16 & 28.1 \\
\hline Not often & 6 & 10.5 \\
\hline Never & 12 & 21.1 \\
\hline
\end{tabular}

Table 2: Functional Performance and Stigma Ratings of Participants. 


\begin{tabular}{|c|c|c|}
\hline Variables & Frequency & Percentages \\
\hline \multicolumn{3}{|c|}{ Bothered By Things That Usually Don't Bother Me } \\
\hline Not at all & 40 & 70.2 \\
\hline A little & 6 & 10.5 \\
\hline Some & 7 & 12.3 \\
\hline A lot & 4 & 7.1 \\
\hline \multicolumn{3}{|c|}{ I Did Not Feel Like Eating } \\
\hline Not at all & 36 & 63.2 \\
\hline A little & 11 & 19.3 \\
\hline Some & 4 & 7.0 \\
\hline A lot & 6 & 10.6 \\
\hline \multicolumn{3}{|c|}{ Happy Despite My Family Wants To Make Me } \\
\hline Not at all & 37 & 64.9 \\
\hline A little & 3 & 5.3 \\
\hline Some & 8 & 14.0 \\
\hline A lot & 9 & 15.8 \\
\hline \multicolumn{3}{|c|}{ Feeling Good Like Other Kids } \\
\hline Not at all & 11 & 19.3 \\
\hline A little & 6 & 10.5 \\
\hline Some & 4 & 7.0 \\
\hline A lot & 36 & 63.2 \\
\hline \multicolumn{3}{|c|}{ Feeling I Couldn't Pay Attention } \\
\hline Not at all & 24 & 42.1 \\
\hline A little & 10 & 17.5 \\
\hline Some & 8 & 14.0 \\
\hline A lot & 15 & 26.4 \\
\hline \multicolumn{3}{|c|}{ I Felt Down and Unhappy } \\
\hline Not at all & 32 & 56.1 \\
\hline A little & 6 & 10.5 \\
\hline Some & 9 & 15.8 \\
\hline A lot & 10 & 17.5 \\
\hline \multicolumn{3}{|c|}{ I Felt Like I Was Too Tired To Do Things } \\
\hline Not at all & 28 & 49.1 \\
\hline A little & 12 & 21.1 \\
\hline Some & 6 & 10.5 \\
\hline A lot & 11 & 19.3 \\
\hline \multicolumn{3}{|c|}{ I Felt Like Something Good Was Happening } \\
\hline Not at all & 11 & 19.3 \\
\hline A little & 8 & 14.0 \\
\hline Some & 6 & 10.5 \\
\hline A lot & 32 & 56.1 \\
\hline \multicolumn{3}{|c|}{ I Felt Like I Did B4 Didn't Work Outright } \\
\hline Not at all & 37 & 64.9 \\
\hline A little & 2 & 10.5 \\
\hline Some & 8 & 8.8 \\
\hline A lot & 15.8 & 15.8 \\
\hline \multicolumn{3}{|c|}{ I Felt Scared } \\
\hline Not at all & 41 & 71.9 \\
\hline A little & 2 & 3.5 \\
\hline Some & 8 & 14.0 \\
\hline A lot & 6 & 10.6 \\
\hline \multicolumn{3}{|c|}{ I didn't sleep as well as i used to } \\
\hline Not at all & 39 & 68.4 \\
\hline A little & 6 & 10.5 \\
\hline Some & 5 & 8.8 \\
\hline A lot & 7 & 12.3 \\
\hline \multicolumn{3}{|c|}{ I was happy } \\
\hline Not at all & 3 & 5.3 \\
\hline A little & 9 & 15.8 \\
\hline Some & 6 & 10.5 \\
\hline A lot & 39 & 68.4 \\
\hline
\end{tabular}

\begin{tabular}{|c|c|c|}
\hline \multicolumn{3}{|c|}{ I Was More Quiet Than Usual } \\
\hline Not at all & 24 & 42.1 \\
\hline A little & 10 & 17.5 \\
\hline Some & 8 & 14.0 \\
\hline A lot & 14 & 24.6 \\
\hline \multicolumn{3}{|c|}{ I felt lonely and have no Friend } \\
\hline Not at all & 45 & 78.9 \\
\hline A little & 3 & 5.3 \\
\hline Some & 5 & 8.8 \\
\hline A lot & 4 & 7.0 \\
\hline \multicolumn{3}{|c|}{ I Felt Like Kids I Know Were Not Friendly } \\
\hline Not at all & 43 & 75.4 \\
\hline A little & 2 & 3.5 \\
\hline Some & 5 & 8.8 \\
\hline A lot & 7 & 12.3 \\
\hline \multicolumn{3}{|c|}{ I had a Good Time } \\
\hline Not at all & 2 & 3.5 \\
\hline A little & 5 & 8.8 \\
\hline Some & 4 & 7.0 \\
\hline A lot & 46 & 80.7 \\
\hline \multicolumn{3}{|c|}{ I Felt Like Crying } \\
\hline Not at all & 43 & 75.4 \\
\hline A little & 8 & 14.0 \\
\hline Some & 3 & 5.3 \\
\hline A lot & 3 & 5.3 \\
\hline \multicolumn{3}{|l|}{ I Felt Sad } \\
\hline Not at all & 39 & 68.4 \\
\hline A little & 10 & 17.5 \\
\hline Some & 4 & 7.0 \\
\hline A lot & 4 & 7.0 \\
\hline \multicolumn{3}{|c|}{ I Felt People Didn't Like Me } \\
\hline Not at all & 43 & 75.4 \\
\hline A little & 6 & 10.5 \\
\hline Some & 3 & 5.3 \\
\hline A lot & 5 & 8.8 \\
\hline \multicolumn{3}{|c|}{ It was Hard to get Started Doing Things } \\
\hline Not at all & 36 & 63.2 \\
\hline A little & 6 & 10.5 \\
\hline Some & 10 & 17.5 \\
\hline A lot & 5 & 8.8 \\
\hline
\end{tabular}

Table 3: Depression Ratings of Participants.

or caregiver was used to assess perception of the patients' towards their illness. The Center for Epidemiology Study Depression Scale for children was used to screen for depression. Data were summarised using Mean, Standard deviation, Frequency and percentiles. Relationship between variables and depression and felt stigma was explored using Pearson's and Spearman's Correlation Coefficients. Regression analysis was conducted to find the predictors of depression and felt stigma.

\section{Results}

The participants were 30 males and 27 females with mean age of $13.8 \pm 3.3$. Their age of onset of seizure ranged between 1 year and 17 years with mean of $8.74 \pm 4.7$. Their age of presenting in the clinic ranged between 2 years and 17 years with mean of $11.43 \pm 3.8$. Thirtyeight (66.7\%) were Christians, 8 (14.0\%) were Muslim and $11(19.3)$ did not specify their religions. Ten $(17.5 \%)$ were in primary school, 36 (63.2\%) were in secondary school and 11 (19.3) had either drop out of school or did not go to school as a result of their illness. Twentyfive (43.9\%) admitted that the condition was disturbing their education making 2 (3.5) dropping out of school, 7(12.3\%) repeated class and 
14 (24.6\%) had reduced academic performances. Fourteen $(24.6 \%)$ of mothers and $15(26.3 \%)$ of fathers had secondary education while $25(43.9 \%)$ of mothers and $30(52.6 \%)$ of fathers had post-secondary education respectively (Table 1$) .18(31.6 \%)$ of the parents own their house of residence and 39 (69.4 lived in a rented apartment. Twentythree $(40.4 \%)$ of the participants had depressive symptoms. The frequency of the ratings of the participants on CES-DC and CATIS are presented in table 2 and 3 respectively.

There was positive significant correlation between depressive symptoms and each of educational level of the patients and seizure frequency at presentation at the clinic, and educational level of patient and felt stigma (Table 4). Regression analysis revealed that seizure frequency of epilepsy at presentation at the clinic is a predictor of manifestation of depressive symptoms, felt stigma, educational level of the patient and socio-economic status of the parents. Perception of stigma was a predictor to depression.

\section{Discussions}

This study revealed depression to be present in $40.4 \%$ of children and adolescents with epilepsy. This is far more than $28.4 \%$ of that of Adewuya and Ola [27] and 23\% by Dunn et al. [5] but closely related to $33 \%$ reported by Alwash et al. [6]. The difference in our result and that of most of the previous studies $[5,6]$ could have been attributed to environmental and cultural differences. These studies were conducted in the western nations while this study was conducted in Nigeria, an African Country. However, the difference in the result between our study and the findings of Adewuya and Ola [27] which was conducted in the same environment (South-western Nigeria and Clinical setting) may have been due to methodological and instrumental variations. In their study, they used K-SADS while in this study we used CESDC which is children and adolescents specific for screening for depression. Our focus was basically on depression while they explored various psychiatric disorders. Nevertheless, our finding corroborated their report of higher prevalence of depression in Nigeria children and adolescent population than the western world. The higher prevalence of depression in this study can also be attributed to the inclusion and exclusion criteria set for this study. These however may not be strong enough not to generalise our finding.

In this study, $43.9 \%$ of the participants' educations have been affected by their epileptic condition ranging from dropping-out through repeating classes to reduced academic performances. This shows the effect of epilepsy on the upbringing and attainment of the sufferers. To the best of our knowledge, none of the previous studies have focused on this aspect of the quality of life of population of people with epilepsy. The finding that the frequency of seizure at presentation at the clinic is a predictor to depression and felt stigma agreed with previous studies $[6,11,27,28]$ who have reported previous frequency of seizure as a predictor to depression and anxiety. The fact that perception of stigma predicts depression in this study shows that perception of stigma is a major factor in developing depression among children and adolescents with epilepsy. This result corroborates those of previous authors who had reported direct association between perceive stigma and depression in the underage with epilepsy [27-33].

The relationship between seizure frequency and socio-economic status of the parent is a phenomenon we may not be able to explain. However, it reflected the socio-economic impact of epilepsy on both the patient and the family. This corroborated other report on the socioeconomic impact of caring for children with chronic illnesses such as cerebral palsy, and sickle cell anaemia. Parental level of education also had significant effect on the seizure frequencies. This may have been due to the fact that less educated parents are likely to have less knowledge about the condition and the appropriate care required. Our personal experience in the clinic has shown that a child from less educated background has less drug compliance. Hence, relapse and frequent seizure are inevitable.

\begin{tabular}{|c|c|c|c|c|c|c|c|c|c|c|c|c|c|c|c|}
\hline AGE & $\mathrm{AOO}$ & AAP & SEX & CLE & MLE & $\begin{array}{l}\text { FLE } \\
\text { POR }\end{array}$ & OOR & DS & SFAP & SFP & $\mathrm{HHI}$ & PP & FS & & \\
\hline AGE & 1 & $0.4^{* *}$ & $0.6^{* *}$ & $-0.3^{* *}$ & 0.2 & $-0.4^{* \star}$ & -0.2 & $-0.3^{* *}$ & -0.2 & $-0.3^{* *}$ & 0.1 & -0.1 & -0.2 & 0.1 & 0.1 \\
\hline AOO & $0.4^{* *}$ & 1 & $0.6^{* *}$ & 0.1 & -0.1 & -0.1 & 0.1 & -0.1 & -0.1 & -0.1 & -0.1 & 0.1 & -0.1 & -0.2 & 0.1 \\
\hline AAP & $0.6^{* *}$ & 0.61 & 0.1 & 0.2 & -0.1 & 0.1 & -0.1 & -0.2 & -0.1 & -0.1 & -0.1 & -0.1 & -0.1 & -0.1 & \\
\hline SEX & $-0.3^{* \star}$ & 0.1 & 0.1 & 1 & 0.2 & 0.2 & $0.3^{* *}$ & 0.1 & 0.1 & -0.2 & 0.2 & 0.2 & 0.2 & 0.1 & 0.1 \\
\hline CLE & -0.19 & -0.1 & 0.2 & 0.2 & 1 & $0.7^{* *}$ & $0.7^{* *}$ & $0.8^{* *}$ & $0.7^{\star \star}$ & $0.4^{* *}$ & $0.4^{* *}$ & $0.5^{\star *}$ & $0.8^{* *}$ & 0.7 & $0.3^{* *}$ \\
\hline MLE & $-0.4^{\star *}$ & -0.1 & -0.0 & 0.2 & $0.7^{* *}$ & 1 & $0.9^{* *}$ & $0.8^{* *}$ & $0.9^{\star \star}$ & 0.1 & $0.6^{* *}$ & $0.6^{* *}$ & $0.8^{* *}$ & $0.8^{\star *}$ & -0.2 \\
\hline FLE & -0.2 & 0.0 & 0.0 & $0.3^{* *}$ & $0.7^{* *}$ & $0.9^{* *}$ & 1 & $0.8^{* *}$ & $0.8^{\star \star}$ & -0.0 & $0.6^{* *}$ & $0.6^{* *}$ & $0.7^{* *}$ & $0.8^{* *}$ & -0.0 \\
\hline POR & -0.2 & -0.1 & -0.1 & 0.0 & $0.7^{* *}$ & $0.8^{* *}$ & $0.8^{* *}$ & 1 & $0.9^{* *}$ & 0.1 & $0.5^{\star *}$ & $0.7^{* *}$ & $0.6^{* *}$ & 0.8 & -0.1 \\
\hline OOR & $-0.3^{* *}$ & -0.1 & -0.2 & 0.1 & $0.8^{* *}$ & $0.9^{* *}$ & $0.8^{* *}$ & $0.9^{* *}$ & 1 & 0.1 & $0.5^{\star \star}$ & $0.7^{\star *}$ & $0.8^{* *}$ & 0.8 & -0.1 \\
\hline DS & -0.2 & -0.1 & -0.1 & -0.2 & $0.4^{* *}$ & 0.1 & -0.0 & 0.1 & 0.1 & 1 & $0.6^{* *}$ & -0.0 & 0.1 & 0.1 & -0.2 \\
\hline SFAP & $-0.3^{* *}$ & -0.1 & -0.1 & 0.2 & $0.4^{* *}$ & $0.6^{* *}$ & $0.6^{* *}$ & $0.5^{* *}$ & $0.5^{\star \star}$ & $0.6^{* *}$ & 1 & $0.6^{* *}$ & $0.4^{* *}$ & $0.6^{* *}$ & -0.1 \\
\hline SFP & 0.1 & 0.1 & -0.0 & 0.2 & $0.5^{\star *}$ & $0.6^{* *}$ & $0.6^{* *}$ & $0.7^{* *}$ & $0.7^{\star *}$ & -0.0 & $0.6^{* *}$ & 1 & $0.4^{* *}$ & $0.6^{* *}$ & -0.0 \\
\hline $\mathrm{HHI}$ & -0.1 & -0.1 & -0.0 & 0.2 & $0.7^{* *}$ & $0.8^{* *}$ & $0.7^{* *}$ & $0.8^{* *}$ & -0.2 & 0.1 & $0.5^{\star *}$ & $0.6^{\star *}$ & 1 & $0.7^{* *}$ & -0.1 \\
\hline PP & -0.2 & -0.2 & -0.1 & 0.1 & $0.8^{* *}$ & $0.8^{* *}$ & $0.8^{* *}$ & $0.6^{* *}$ & -0.1 & 0.1 & $0.4^{* *}$ & $0.4^{* *}$ & $0.7^{\star *}$ & 1 & 0.1 \\
\hline FS & 0.1 & 0.1 & -0.1 & 0.1 & $0.3^{* *}$ & -0.2 & -0.0 & -0.1 & -0.1 & -0.2 & -0.1 & -0.0 & -0.1 & 0.1 & 1 \\
\hline
\end{tabular}

KEY: **significant at $p=0.00 ;$ AGE = Child's age; AOO = Age of Onset; AAP = Age at presentation; SEX = Child's sex

$\mathrm{CLE}=$ child's educational level; MLE = Mother's educational level; FLE = Father's educational level; $P O R=$ Place of residence

$\mathrm{OOR}=$ Ownership of residence; $\mathrm{DS}=$ Depression symptoms; SFAP = Seizure frequency at presentation; SFP = Seizure frequency at present

$\mathrm{HHI}=$ House-hold income; $\mathrm{PP}=$ Personal possessions; FS=Felt stigma 
This study has been able to provide more information on the prevalence of depression in children and adolescents with epilepsy in the tropics and in comparison with the temperate. It has also provided more evidence on the predictors of depression in children and adolescents with epilepsy. We have employed population specific instrument which has helped us with specific variables coupled with our thorough assessment and team work (multi-disciplinary approach) in extracting our facts. We acknowledge the fact that this study is clinic-based and this may have limited the sample size. This shows the need for a broader study that will be community-based. The issue of mixed diagnosis which are common in epilepsy was a major limitation to this study. This affected the final sample size. However, effort was made to ensure that all patients diagnosed of epilepsy in the Centre were included in the study.

\section{Conclusion}

This study has been able to provide more information on the higher prevalence of depression in Nigeria children and adolescents with epilepsy relative to their western-world counterparts in a hospital-based setting. We have also showed that epilepsy has negative impact on the psychosocial status of children and adolescents in Nigeria. Therefore, there is need to pay more attention to children with epilepsy to reduce the frequency of seizure so as to improve their psychosocial wellbeing.

\section{References}

1. Devinsky O (2003) Psychiatric comorbidity in patients with epilepsy: implications for diagnosis and treatment. Epilepsy Behav 4: S2-S10.

2. Plioplys S (2003) Depression in children and adolescents with epilepsy. Epilepsy Behav 4: S39-S45.

3. Plioplys S, Dunn DW, Caplan R (2007) 10-year research update review: psychiatric problems in children with epilepsy. J Am Acad Child Adolesc Psychiatry 46: 1389-1402.

4. Thome-Souza S, Kuczynski E, Assumpção F Jr, Rzezak P, Fuentes D, et al. (2004) Which factors may play a pivotal role on determining the type of psychiatric disorder in children and adolescents with epilepsy? Epilepsy Behav 5: 988-994.

5. Dunn DW, Austin JK, Huster GA (1999) Symptoms of depression in adolescents with epilepsy. J Am Acad Child Adolesc Psychiatry 38: 1132-1138.

6. Alwash RH, Hussein MJ, Matloub FF (2000) Symptoms of anxiety and depression among adolescents with seizures in Irbid, Northern Jordan. Seizure 9: 412-416.

7. Piazzini A, Canevini MP, Maggiori G, Canger R (2001) Depression and anxiety in patients with epilepsy. Epilepsy Behav 2: 481-489.

8. Kanner AM (2002) Psychiatric comorbidity in patients with developmental disorders and epilepsy: a practical approach to its diagnosis and treatment. Epilepsy Behav 3: 7-13.

9. Kanner AM, Balabanov A (2002) Depression and epilepsy: how closely related are they? Neurology 58: S27-S39.

10. Kanner AM, Palac S (2000) Depression in epilepsy: a common but often unrecognized comorbid malady. Epilepsy Behav 1: 37-51.

11. Oguz KK, Senturk S, Ozturk A, Anlar B, Topcu M, et al. (2007) Impact of recent seizures on cerebral blood flow in patients with sturge-weber-syndrome: study of two cases. J Child Neurol 22: 617-620.

12. Baker GA, Brooks J, Buck D, Jacoby A (2000) The stigma of epilepsy: a European perspective. Epilepsia 41: 98-104.

13. Baker GA (2006) Depression and suicide in adolescents with epilepsy. Neurology 66: S5-S12.

14. Kanner AM (2008) Depression in epilepsy: a complex relation with unexpected consequences. Curr Opin Neurol 21: 190-194.

15. Beyenburg S, Mitchell AJ, Schmidt D, Elger CE, Reuber M (2005) Anxiety in patients with epilepsy: systematic review and suggestions for clinical management. Epilepsy Behav 7: 161-171.
16. Harden CL, Goldstein MA (2002) Mood disorders in patients with epilepsy: epidemiology and management. CNS Drugs 16: 291-302.

17. Hoie B, Sommerfelt K, Waaler PE, Alsaker FD, Skeidsvoll H, et al. (2006) Psychosocial problems and seizure-related factors in children with epilepsy. Dev Med Child Neurol 48: 213-219.

18. Davies S, Heyman I, Goodman R (2003) A population survey of mental health problems in children with epilepsy. Dev Med Child Neurol 45: 292-295.

19. Carlton-Ford S, Miller R, Nealeigh N, Sanchez N (1997) The effects of perceived stigma and psychological over-control on the behavioural problems of children with epilepsy. Seizure 6: 383-391.

20. Grabowska-Grzyb A, Jedrzejczak J, Nagan'ska E, Fiszer U (2002) Risk factors for depression in patients with epilepsy. Epilepsy Behav 8: 411-417.

21. MacLeod JS, Austin JK (2003) Stigma in the lives of adolescents with epilepsy: a review of the literature. Epilepsy Behav 4: 112-117.

22. Marsh L, Rao V (2002) Psychiatric complications in patients with epilepsy: a review. Epilepsy Res 49: 11-33.

23. Pellock JM (2004) Defining the problem: psychiatric and behavioral comorbidity in children and adolescents with epilepsy. Epilepsy Behav 5: S3-S9.

24. Sabbagh SE, Soria C, Escolano S, Bulteau,C, Dellatolas G (2006) Impact of epilepsy characteristics and behavioral problems on school placement in children. Epilepsy Behav 9: 573-578.

25. Sbarra DA, Rimm-Kaufman SE, Pianta RC (2002) The behavioral and emotional correlates of epilepsy in adolescence. a 7-year follow-up study. Epilepsy Behav 3: 358-367.

26. Titus JB, Kanive R, Sanders SJ, Blackburn LB (2008) Behavioral profiles of children with epilepsy: parent and teacher reports of emotional, behavioral, and educational concerns on the BASC-2. Psychology in the Schools 45: 892-904.

27. Adewuya AO, Ola BA (2005) Prevalence of and risk factors for anxiety and depressive disorders in Nigerian adolescents with epilepsy. Epilepsy Behav 6: 342-347.

28. Adewuya AO (2006) Parental psychopathology and self-rated quality of life in adolescents with epilepsy in Nigeria. Dev Med Child Neurol 48: 600-603.

29. Turky A, Beavis JM, Thapar AK, Kerr MP (2008) Psychopathology in children and adolescents with epilepsy: an investigation of predictive variables. Epilepsy Behav 12: 136-144.

30. Vazquez B, Devinsky O (2003) Epilepsy and anxiety. Epilepsy Behav 4: S20S25.

31. Austin JK, Dunn DW, Caffrey HM, Perkins SM, Harezlak J, et al. (2003) Recurrent seizures and behavior problems in children with first recognized seizures: a prospective study. Epilepsia 43: 1564-1573.

32. Austin JK, Dunn DW, Johnson CS, Perkins SM (2004) Behavioral issues involving children and adolescents with epilepsy and the impact of their families: recent research data. Epilepsy Behav 5: S33-S41.

33. Tosun A, Gokcen S, Ozbaran B, Serdaroglu G, Polat M, et al. (2008) The effect of depression on academic achievement in children with epilepsy. Epilepsy Behav 13: 494-498. 